Makale Geliş | Received: 19.09.2019

Mavi Atlas, 7(2)/2019: 150-176

Makale Kabul | Accepted: 03.10.2019

DOI: 10.18795/gumusmaviatlas.614185

\title{
Gamze AKSAN
}

Dr. Öğr. Üyesi| Assist. Prof. Dr. Selçuk Üniversitesi Edebiyat Fakültesi Sosyoloji Bölümü, Konya-TÜRKIYE Selcuk University, Faculty of Letters, Department of Sociology, Konya-TURKEY

ORCID: 0000-0001-5051-4630 gaksan@ selcuk.edu.tr

\section{Globalization and Civil Society or "Global Civil Society"}

\begin{abstract}
The idea of civil society has brought along various meanings and concepts in the historical process. Civil society, which gained more importance with the modern era, has gained a complex structure with globalization, which is a much more visible process in the 21 st century. In particular, cultural diversity, the existence and demands of different social groups in social life, social movements, transportation and communication facilities; differentiated globalization and civil society. This, in a way, has led to a broader reading of political life. In this study, the ties and relationship between globalization, a historical process and reality, and the concept of civil society emerged in the 21 st century has been tried to be revealed. For this purpose, the historical development of civil society has been included in the study. In the following sections, the issue of globalization, democratization and civil society has been discussed and finally, inferences regarding the perception of global civil society which constitute the body of the study have been made.
\end{abstract}

Keywords: Civil Society, Globalization and Democratization, Global Civil Society.

\section{Küreselleşme ve Sivil Toplum veya "Küresel Sivil Toplum"}

\section{$\ddot{O} \mathbf{z}$}

Sivil toplum düşüncesi tarihsel süreç içerisinde çeşitli anlam ve kavramlarla ilişkilendirilerek kullanılmaktadır. Modern dönemle birlikte daha da önem kazanan sivil toplum, 21. yüzyılda çok daha görünür bir süreç olan küreselleşme ile birlikte kompleks bir yapıya kavuşmuştur. Bilhassa kültürel çeşitlilik, farklı toplumsal grupların sosyal yaşamdaki varlığı ve talepleri, toplumsal hareketler, ulaşım ve iletişim olanaklarında meydana gelen kolaylıklar; farklılaşan bir küreselleşme ve sivil toplum algısını ve pratiğini doğurmuştur. Bu durum, bir açıdan da politik yaşantının daha geniş bir ölçekte okunmasına vesile olmuştur. Peki, gerçekte küresel bir sivil toplumdan bahsedilmek mümkün müdür? Bu çalışmada, tarihsel bir süreç ve gerçeklik olarak küreselleşmenin 21. yüzyılda ortaya çıkan sivil toplum kavramıyla bağı ve ilişkisi ortaya konulmaya çalışılmıştır. Bu amaçla çalışmada başta sivil toplumun tarihsel gelişimine yer verilmiş, ilerleyen bölümlerde küreselleşme, demokratikleşme ve sivil toplum ilişkisine değinilmiş ve son olarak çalışmanın merkezî problemi olan küresel sivil toplum konusu ele alınarak bazı değerlendirmelerde bulunulmuştur.

Anahtar Kelimeler: Sivil Toplum, Küreselleşme ve Demokratikleşme, Küresel Sivil Toplum. 


\section{Gamze AKSAN, "Globalization and Civil Society or 'Global Civil Society", \\ Mavi Atlas, 7(2)/2019: 150-176}

\section{Introduction}

As it is known, the most popular side of the 19th century, where many radical developments had been experienced, is highly and directly connected with the industrial revolution. With the industrial revolution, the economic circle of the development had gained momentum. At the same time, technological development had brought a set of novelties that had never been experienced in the human history; especially in the 1800s which had given way to developments that started in Western Europe and expanded to entire World. The process that had started with the textile industry had provided other developments on bigger changes in terms of industrial operation and machine manufacturing and also the area of chemistry in a very short term. In addition, one of the important developments is about transportation, observed as the embodiment of globalization due to exploitation movements, which gave shape to the history of humanity as an intensive dependency.

It is clear that all of these developments mentioned above cause structural and functional differences in social relationship. In large cities where their characteristics are mainly determined by the notion of industry, the necessity of different heterogeneous groups, which never know each other, cannot solve/burden the problems/necessities via informal relationships that are very different in terms of socio-economic and sociocultural situation, and the areas where they can feel common sense have increased; also, within this context, new collective movements have emerged. The process of spreading of aforementioned technological and industrial changes through transportation and communication causes the awareness of the problems that were spoken culturally or politically. This also widened the common discourse areas in a transnational way. This mentioned process in fact is directly connected with the today's civil society. Even though the initial practices regarding civil society, which has been evaluated from the 18th century to today, had developed within the circle of "political society", in the process of today, it is possible to claim that collective right movements are more visible in West and they are determinant about the route of the movements after the 1950's and there is a civil society area that has been getting stronger and spreading after the 1990's, which specific concerns are generalized in a global scale. In fact, one of the most important dynamics that determines the process in which the concept of civil society actually begins to develop as an academic interest in social sciences is globalization. In time, beside economic notions that were directly affected by industrialization and market conditions, the basis of nation-state had been started to be questioned through the widening discussion areas regarding human rights and freedom. As such, new citizenship approaches such as 


\section{Gamze AKSAN, “Globalization and Civil Society or 'Global Civil Society"”,}

Mavi Atlas, 7(2)/2019: 150-176

multicultural citizenship and global citizenship were brought on the agenda by the growing debate on individual rights and freedoms and they also influenced the perception of citizenship. All of these developments directly shaped the sphere of civil society, and within the context of "social movements", the process we are discussing today has brought a new platform to a more concrete theoretical and practical expression.

By the development of information technologies, the process has gained momentum and it has been supported by the creation of different areas where common civic reflexes can be developed. Therefore, this study proposes to shed light on the points where civil society and globalization are coinciding within historical process.

This study thus aimed at revealing the points that civil society in history has intersected with globalization. In this essay, firstly, conceptual and theoretical frameworks related to civil society will be given. After examining the civil society context that emerged in the approach of state and society, which is an important discussion axis in the political literature, the dimensions of civil society impact of globalization will be examined and the frame and possibilities of "global civil society" will be evaluated.

2. Main Thoughts on the Concept of Civil Society within the Circle of Discussions on State and Society

In general, civil society, which is a concept of western origin, is characterized by analytical concepts, where qualitative and quantitative descriptions of the state, the individual and the society are determined in many theories. Hence, the concept emerges as a concept that presents different semantic integrations in different historical periods and found in discussions about political theory where the theorists mostly fill the content of their main focus. For example, the word "civil" keeps a meaning such as city custom and civilization, especially reflecting the nature of the 18th century; it is used by some Western thinkers to express freedoms through individual freedoms (Bolay 1997: 7). The classic use of the concept, which extends from Cicero among the ancient Greek philosophers and other Roman thinkers in terms of its roots, remains in the state until the end of the 18th century (Rowley 1997: 401). In its contemporary context, the modern civil society idea, i.e. the context of fundamental rights and freedoms that an individual obtains in the face of the state, has become evident in the Scottish and Continental Enlightenment in the late 18th century. This normative ideal, which came to the fore with the collapse of the social order crisis and the regulatory paradigms in the western societies in the late 17th and 18th centuries (Seligman, 2002: 14), was discussed by many political theorists from Thomas Paine to Georg Hegel in a context where the citizens could 


\section{Gamze AKSAN, “Globalization and Civil Society or 'Global Civil Society",}

Mavi Atlas, 7(2)/2019: 150-176

participate in the direction of their own interests and desires and developed it as a field parallel to the state but separate from it. This new idea was the reflection of the private property, the market competition and the changing economic situation with the rise of the bourgeoisie. This situation became a fallacy in the cabin by merging of the demands of liberty that emerged with the American and French revolutions (Carothers 2000: 18). Especially during the seventeenth century, land, labor, the commercialization of the capital, the expansion of the market economy, the developments around new discoveries and revolutions resulted by the questioning of existing political order and authority. At the end of the century, concepts such as God, king, state, individual, woman, and man existed in the traditional political culture of the West were refilled according to requirements of the modern world and the basic elements of political system were attempted to be re-defined (Çaha 2003: 23-24). Thus, by the seventeenth century, social theorists who lived in the eighteenth and nineteenth centuries focused on the state-society relationship by discussing the qualities of the political structure that will be formed under the influence of liberalism, Marxism or conservative thought systems, especially the new social order determined by the industrialization. The next process was shaped by the differing demands of the changing social structure, and the concept of civil society was mainly dealt with in relation to democracy for being influenced by the popularization of civil rights demands in the 1960s and the developments experienced in the 1980s.

Historically, theoretical discussions of the state and individual / community focus have historically been seen as the forefront of the two fundamental approaches set out by the French and Anglo-Saxon political reflexes, as well as the Marxist perspective articulated in the nineteenth century in civil society debates. These considerations represent two central trends in the discussion, suggesting two analytical frameworks, both transcendental and instrumental. The state-oriented political thought has turned into a structure which extends to the origin of Plato and leads to a structure that promotes and politicizes the same sensitivity on a national basis by rejecting the legitimacy of the religion-based understanding in the modern world, leaving a transcendentalism built in the minds of Machiavelli and Bodin (Çaha 2003). The subject that comes to forefront in this perspective is that the state becomes a "purpose" with the transcendental and surrounding aspects; on the other hand, the field of civil society is very narrow in terms of individual freedoms and open to state intervention. It is a subject of state-society relationship in which the autonomy of the state authority is important and as well as the obedience of individual's to this authority. 


\section{Gamze AKSAN, “Globalization and Civil Society or 'Global Civil Society",}

The views that provide the most important perspectives to the "purpose"-based configuration of the state belong to Hobbes. According to Hobbes (1977), in the case of nature, man is a wolf to man, which means anarchy and chaos. The state, on the other hand, came up with this justification in order to ensure the individual safety of the people. This security will not be provided by natural law, so we will need a power that will force us to comply with some rules, and this power will only be possible with a continuous, decisive mechanism, rather than a combination of several people or families. The only way to build such a general power that will enable individuals to live in peace is through the transfer of everyone's will and judgment to a single will. The willpower mentioned here is the social contract which symbolizes the will of everybody. Thus, Hobbes states that the source of the state's absolutism is the existence of a social contract besides a sacred power, and the idea of the state is at a different level. However, Hobbes' views set the state in a very comprehensive way, and grant virtually unlimited power to this structure, which has legitimacy for everyone to represent his will (Keane 1994: 63). All civil society elements, including religious institutions, should be gathered under the roof of the state. Since the state is the maker of all kinds of laws, religious law will not be needed, and obedience to the state will mean the worship of God at the same time. Therefore, the civil society in Hobbes was actually a demonstration of civil status as a counterpart to natural rights (Akal1 1991: 118-119) and a peaceful order that the security state had forcibly provided (Keane 1994: 63).

Rousseau, another thinker who can be appreciated in this tradition, differs from Hobbes in the sense that people in nature are "naturally good". According to Rousseau, liberating the individual is directly involved in making the law. In this context, Rousseau, as a necessary element for political freedom, reintroduces re-existence in a certain way to the virtues of the citizens of ancient Greece and Rome. According to him, subordination of individuals to the immovable authority of a common organ prevents them from being personally dependent. As an individual, each person has a "special will" that serves "special interest". However, as "citizen", each one participates in general will by serving the common interest of the citizen (Anhart 2004:196). Thus, in order to live in peace and to preserve their own property, the individuals will transfer the "special" and "different" wills to the general will that surrounds and encompasses the contracts they have executed with their own survival. After the formation of the general will, individuals lose their difference and become bearer of this interest. As special initiative and extension situations lead individuals to rational egoism, differences in the public arena must be transformed into an absolute harmony. With this view, Rousseau gives signs of an authoritarian state 


\section{Gamze AKSAN, “Globalization and Civil Society or 'Global Civil Society"”,}

Mavi Atlas, 7(2)/2019: 150-176

position in terms of civil society in the modern world. At first, Rousseau attains a level of civil society level differences that reaches an inclusive state and public sphere, although the individual's interests and involvement seem important (Çaha 2003: 29). In this way, it is possible to evaluate this perspective within the statist tendency.

Hegel is one of the thinkers who clarify the distinction between state and society, as well. According to Hegel, civil society is a level of distinction that requires the state to be able to achieve itself, but mediates between the state and the family, even if the development is precisely following the state (Hegel 2010: 210). Civil society is not a state of natural liberty; it is a patriarchal, ethical living space between the family and the state produced in the historical process. This area covers institutions responsible for the execution of economic, social classes, professional associations and prosperity and civilized law. In this sense, civil society is a mosaic composed of private individuals, classes, groups and institutions whose activities are governed by civilized legal rules and whose qualities are not directly linked to the political state itself (Keane 1994: 76). In Hegel's thought, the civil society does not only separate state and the family, but also directly contributes to the individual's direct participation in various social institutions (Ritzer 2010: 131). The creation of civil society as a product of a long and historically complex process is in fact the success of the modern world (Hegel 2010: 308). The bourgeois society he describes is one of the specific social forms that have emerged historically. It is a vital condition, even though it is not completely dispatched to its civil society economic institutions.

Even though his thought of civil society does not completely refer to economic institutions, these are vital conditions in his position. For Hegel, the possibility of preserving both individual freedom and the universal state is based on all the innovations of the new class and social life that emerged, and a different and autonomous economy, instead of subordination of one to another as it was done in previous societies. This new social life meets private and public, individual and universal with the interplay of special interests; neither merely the family nor the state, but both are intermediaries (Wood 1990: 62). However, the field of civil society is a battlefield where Hegel's approach is exposed to fragile and serious conflicts as opposed to the family that represents the area of harmonization, and where conflicts of special interests conflict with private interests. Because of this persistent nature, it requires political regulation because it cannot resolve its conflicts by itself. Only then a high public authority can overcome the injustices of civil society and synthesize the interests of a particular within a universal political community (Keane 1994:77: 48). Although Hegelian approach with the idea of an upper 


\section{Gamze AKSAN, "Globalization and Civil Society or 'Global Civil Society", Mavi Atlas, 7(2)/2019: 150-176}

and a dominant authority for civil society to realize itself shares the same emphasis with the statist tradition in its outcome, it is important to select civil society as the starting point and to centralize the historiography.

Individual and community-based tradition is usually handled within the framework of Ferguson, Locke, Mill, Berlin and Hayek. When these considerations are evaluated, Ferguson, for example, emphasizes the necessity of establishing and strengthening citizen units for the revival of the public soul in order to prevent the despotic political society from narrowing the field of civil society and restricting individual rights and freedoms. But in the last stage, he feels that the separation of the political and civil sphere is dangerous for management and consequently opposes to this idea (Aslan 2010: 196). John Locke is one of the first thinkers to come to mind in an individual-centered thought. John Locke's views on the state-centered thinking of how the state, equipped with as much power and authority as possible to put an end to the chaotic climate, can suppress its own excesses later on, have important implications for the formation of an individual-centered thinking in the state and society debate. According to Locke, in the case of nature, man is in the form of freedom, peace and mutual aid (exactly the opposite of Hobbes' thoughts). Conflict or war is one of the obvious threats to the human being in nature. In this framework, the political authority was established with the aim of protecting the state against the risk of war (Pollock 1904: 242-243). Locke is convinced that the state's admissible side is to respect the equal rights of individuals and serve their common interests (Rawls 2003:29). In Locke's mind, Civil society expressing life in "peace, trust and peace" consists of a stable interaction between male, "free, equal and independent" individuals; the properties possessed by these individuals are assured in the broadest sense by means of subordination to the state politically, that is, the process of formulating, executing and enforcing the laws in a single state (Locke 1823: 146; Keane 1994: 67). In the face of sovereignty of the unrestricted state, Locke opens civil society space in terms of state proposal, which is legally guaranteed arbitrator allowing individual rights and freedoms through this approach. Here, in particular, the arguments concerning the state of natural social solidarity are based on the view that the state is supposed to complement the aspects that are lacking in nature and to be present in a compromising manner by contrasting the viewpoint that the state is designed as an absolute sovereign power covering all social and individual spheres due to the chaotic nature of the state of nature.

Mill, Berlin, and Hayek were the other important figures who stood in opposition to the statist political tradition and contributed to the development of modern civil society 


\section{Gamze AKSAN, “Globalization and Civil Society or 'Global Civil Society"”,}

Mavi Atlas, 7(2)/2019: 150-176

thinking, with individual approaches such as freedom, diversity, pluralism and participation. While they do not suggest a direct theoretical framework for the concept of civil society, their approach to the core contexts of the concept is of great importance. For example, J. Stuart Mill argues that the civil and political dimension of social life must be built on a diversity that is based on tolerance. Mill, reflecting the difference in human nature in social life, establishing a society project open to diversity and differences and pointing to the necessity of an independent state, thinks that the state should accept individual freedoms in their own diversity. In addition, Mill pointes out differences that are one of the important elements for the development of civil society and claims the freedom of individuals based on ethnic or gender based group ties by moving beyond the basic discourse about the subject (Çaha 2003: 49-50). Isaiah Berlin draws attention to the individual freedoms and the areas restricted by the negative and positive freedom approach. Freedom, however, does not reveal humanity as the sole purpose. To treat others as if they did not want them to treat themselves, to pay the debt to those who were capable of freedom, prosperity and enlightenment alone; that is, the simplest and most universal meaning, justice, equality of freedom. According to Berlin, this framework is the basis of liberal morality (Berlin 1969: 124-126). There is more than one way to live a good and beautiful life. Berlin, who claims that one of these ways is the best one, will take a monstrous structure, regardless of who comes from it, foresees a pluralistic political model in which it can be realized by fervently advocating moral values at the point of pluralism (Çaha 2003: 51). The emphasis on Hayek's approach can be read through criticism of state intervention and totalitarianism. For example, Hayek (1995: 150; 1999: 131), who thinks that even a small intervention into economic life in the name of social justice will lead society to slavery, and that state intervention in the market will cause individuals to fulfill their destinies and subject the state to the hierarchy of aims, the civilian area gives signs of places to be confined, while increasingly worried that it will grow into a repressive and totalitarian structure.

In the theoretical background of the concept of civil society, a different axis, beyond the emphasis of statist or socialist, was formed within the framework of Marxist views. These approaches, which we can also refer to as a Marxist state conception, are approaches that distinguish civil society from the state and tend to see the state as the determinant of the entire public interest in capitalist societies. When we consider Marx's views on civil society as a source, some differences between statist or individualist or socialist political tendencies attract the attention. First of all, Marx does not regard civil society as a natural state, but in fact it emphasizes the historicity of the concept parallel 


\section{Gamze AKSAN, “Globalization and Civil Society or 'Global Civil Society",}

Mavi Atlas, 7(2)/2019: 150-176

to its own point of view. Civil societies under modern state guarantees are defined as the product of its historicity in terms of its production relations and forces. In civil society, which reflects the economic form that the bourgeoisie has imitated by its image, the bourgeois competition and selfishness leads to the dissolution of previous natural bonds. The means to be used only in the face of individuals for their own specific purposes and the various social bonds in the form of an external necessity emerged only in the 18th century (Keane 1994: 92, 93). Marx is disturbed by the fact that the idea of a public interest, which is pursuing individual interests, has begun to be formed by focusing on relations in bourgeois society. Civil society will create power in itself and ultimately disrupt or change the existing structure of the proletariat (Cox 1999: 6). In addition, Marx points out that the view of civil society and the state as two separate units hindered the recognition of the dimension of subordination to economic activities and organizers of the state (Aktay 2015: 298). Thus, by criticizing the universality of the state, the characteristics of the civil society it emphasizes, and class relations, Marx transforms Hegel's distinction between state and civil society. This has also led Marx to the discovery of a civil society anatomy within his criticism of political economy at the same time in his life. The divergence of opinion on the distinction between state and civil society was a precondition for Marx's analysis of capitalism. But this analysis lacks Hegel's justification for diversification (Wood 1990: 62).

Marx accepted the state as an institution of sovereign power, not as an inclusive institution that possesses universal rules and meets the needs of the nation. In this sense, the state is a reflection of civil society, not an upper institutional synthesis that reconciles conflicts in civil society. Civil society is not lost in the body of the state; it is reproduced. Because the class which is strong in civil society, that is to say the class which has the means of production, determines both the state and its quality, it actually turns the rules of civil society in its behalf (Çaha 2003: 38). Thus, civil society is a historical phenomenon that owes its capitalization to capitalism as the area of production and class struggle.

A detailed discussion on civil society in Marxist literature was made by Antonio Gramsci. Gramsci identifies two basic superstructure levels. One of them is civil society and the other is political society, that is, the state. These two levels correspond to the hegemony function that the ruling class imposes on the society and the function of command applied through the state or legal power. Gramsci, like Marx, sees civil society as a fundamental factor in recognizing capitalist development, but for Gramsci, the effective and positive effect of historical development is not due to the production 


\section{Gamze AKSAN, “Globalization and Civil Society or 'Global Civil Society"”,}

Mavi Atlas, 7(2)/2019: 150-176

relations, the institution of infrastructure. On the contrary, the superstructure represents this situation. The integrity of ideological and cultural relations, spiritual and intellectual life, and the political expression of these relations are at the center of Gramsci's analysis. Civil society, on the other hand, is not directly related to the subordinate structure, which is directly related to the production relations of the ruling class, as Marx has in his mind. Gramsci emphasizes hegemonic associations at this point. Hegemony is the ideological superiority of ruling classes over dependent classes in civil society (Carnoy 2001: 255, 256). The elements that constitute the field of civil society are of great importance for the hegemony to be broken. In order to be able to challenge the hegemony of the state, controlled by the market and dominated by the family itself, the opposition must acquire positions in civil society (such as universities and the media). The opposition can only produce its own ideas in this form against the hegemonic ideas that arise from the capitalist economic system (Ritzer 2010: 131).

The tradition that emphasizes the state in civil society debates includes approaches that reveal the distinction between civil society and the state, but the approaches that enable the realization of the practical contribution to the benefit of the individual and society are within the individualist or socialist political tradition that reveals the instrumental aspects of the state. While the phenomena that characterize the civilian field such as variety, diversity and individual freedoms took place in this tendency, the practical side of civil society became more visible through the increasing influence of different characters and globalization in the 1900's and this concept became more and more debatable through different and concrete levels in the process. Although globalization refers to changes and interactions in many areas of economic, political, cultural, political areas, especially the context of civil society, which is evident for a few decades, is related to democracy. In this framework, civil society, which is an analytical concept in the state and society debates, and showing the boundaries of both sides, has begun to be evaluated in terms of more concrete and functional aspects. Now let's take a quick look at these issues.

\section{Globalization, Democratization, and Civil Society}

Classical approaches regarding civil society have made some propositions on the individual and community boundaries of the state in modern society. However, the concept signalizes too much concrete levels through the discussions on public sphere and democratic rights and demands for today's societies. 


\section{Gamze AKSAN, “Globalization and Civil Society or 'Global Civil Society"”,}

Mavi Atlas, 7(2)/2019: 150-176

At the centre of references to democracy, Tocqueville's views are more prevalent. Unlike the thinkers we talked about before, Tocqueville is concerned with the aspects of civil society that provide social organization by drawing a concrete framework based on democracy, and stresses the power to reveal the potentials of relationships among individuals. One of the examples given by Tocqueville at this point is about the comparison among French and American revolutions. Surprisingly, the revolution of the French society had two opposing influences: liberty and despotism. While the revolution emphasized liberty and equality on one side, the intermediary institutions between the people and society were destroyed because on the other side it was quite destructive and bloody. This double character of the Revolution was skillfully ruled by those in possession of absolute power. But in the case of America (perhaps because of the lack of an aristocratic class with the reason of its own historical specificity), the people could cope with their own problems without being touched by the state and could solve the problems they faced with solidarity and cooperation by establishing foundations and associations. (Tocqueville 2002: 114, 115, 168, 248). In this context, a wide variety of organizations, such as religious or moral, with no political character and orientation could have been formed. Such organizations allowed people to build mutual relationships with each other, allowing them to develop new and long-lasting emotions, thoughts, passions and understanding, allowing people to hold onto each other and act in the same time. If it were not for such organizations, the actions of people and their willingness to act would be scarce in an age that would not be appropriate (Ritzer 2010: 131). Thus, civil society could only fulfil its vital role in social relations by being present in an environment where the state is not despotic and more democratic elements have developed.

Another contribution of Tocqueville, which emphasized the more practical aspects of the positive functional features of the civil society in the modern society, was the mission of civil society he formed in the functioning of democracy. Touching on the danger of the rise of a new "type of state despotism" chosen by the people, Tocqueville is convinced that the formation and development of civilian units, which are outside the control of the political institutions, as well as the control of the state institutions, are necessary to prevent this new electoral state of despotism. In this sense, civil unions, unlike the forms of political interest that focus on the broader and general interests of the community, are formed by the union of citizens engaged in "small affairs" and at the same time provide the opportunity to discuss more comprehensive issues that concern the whole political community. But more importantly, these units reinforce local and national freedoms, which are essential for maintaining democratic equality and preventing tyranny 


\section{Gamze AKSAN, “Globalization and Civil Society or 'Global Civil Society"”,}

Mavi Atlas, 7(2)/2019: 150-176

over the minority of the majority (Keane 1994: 80, 81). While Tocqueville's approaches, which reveal important aspects of civil society elements for today's modern nation states, draw a more practical framework, civil society is of vital importance as an element that actually inspires and develops democracy. Interpretations in this centre help to clarify the issues that democracies should respond to democracies as modern forms of governance, how to differentiate in every aspect of society and the increasing demands for rights, and the attitude that the state should attach to society and the state in relation to the state, from the centre of civil society.

In the on-going global debate, it is emphasized that the concept of civil society is central to democracy and democratization. At the same time, in connection with more upto-date discussion areas such as social capital and communication networks, an efficient reservoir of social capital has become a widespread belief that a wealthy civil society has come to fruition. Indeed, this is closely related to the process by which civilization, which is increasingly influenced by globalization as one of the practical consequences of civil society, is evolving into the civilian formations in which the development of communication networks and the acceleration of the flow of information can be influenced and transformed into potential benefits. This widespread opinion makes this concept to be perceived as a vital precondition for liberal democracies (Vinod and Meena 2013: 284). When we evaluate more current definitions of civil society's place and function in the modern state, we see that the concept and the social reality pointed out are directly related to democracy. For example, Giddens (2016: 1098; 2003: 77, 78) emphasizes the realization of democratic attitudes, including tolerance, in defining civil society, family, schools, community organizations and institutions outside the economy, together with "the area of activity between the state and the market. The area where the stamp of democratic citizenship strikes must be raised from the bottom up with a vibrant culture of citizenship, which should be cultivated by the government as well as culturally based. Even if the free market environment and economic stability are provided alone, this is not enough. Economy, government and civil society need to work in balance. One's dominance over the other could cause that civil society will lose its presence, as seen in the example of the former Soviet Union, where the state intervened in most areas of life and was overly dominant. Ernest Gellner (1994) has established an almost ontological link between democracy and civil society, and sees civil society as a condition for the existence of democracy. Civil society is an independent and powerful balance mechanism for the state beyond reflecting non-governmental institutionalities or cohesion (Malesevic and Malalesevic 2009: 4). As an ideal and action area, Kaldor (2007: 154) sees civil 


\section{Gamze AKSAN, “Globalization and Civil Society or 'Global Civil Society"”,}

Mavi Atlas, 7(2)/2019: 150-176

society as a process in which individuals debate, fight and understand both with each other and with political and economic centers of power. In this framework, individuals act in the context of voluntary organizations, social movements, parties and trade unions and all these are realized in the public arena.

The political theorist John Keane (1994: 308, 309), who discusses the issue of democracy and civil society in-depth, emphasizes the danger of monopolizing political power in democratic settings, emphasizing that political power is often manipulated and diverged from extremes to become central and inclusive by frequent change of power; thus, despotism will come down the most. This must be realized by political controls over state power, which should be reinforced by civilian units that are outside the direct provision of institutions. Civil unions undoubtedly allow citizens to negotiate wider and more comprehensive initiatives involving the entire social and political system. But beyond that, it nurtures and deepens local and secular freedoms that are essential to resist ideology development, to express singular interests effectively, and to secure the complex equality and freedom of individuals and groups. It is an implicit condition that the concept of democracy and the social evaluation of its principles - and not abandonment and adherence to them - can be discussed. However, in practice this assessment requires a pluralistic civil society protected by an open and responsible state.

Then, is it possible to provide a framework that provides the guarantee of civil society, which is necessary for civil society to form and to exist in contemporary societies? For example, Çaha (2003: 58-59) draws attention to some of the necessary preconditions that the state and society must carry at this point. To be a state of law requires ensuring that every citizen is accepted in equal status that fundamental rights are not restricted in any way, and that managers should avoid arbitrary attitudes. At the same time, it is possible that the recurrent state, which will take place among civil society organizations in cultural, political and economic fields in social life, is not a party but a state of law. Since the main tasks of the state are limited to justice, defense and security activities, it will create a vibrant atmosphere by attracting civil society elements to the remaining service areas. The more the state has economic, political and cultural presence, the narrower the field of activity of civil society.

The preconditions that social life must have for civil society to be able to show up and develop are expressed as social differentiation, social organization, voluntary unity, autonomy at the social level and formation of the pressure mechanism. This requires a social base where there is an ethnic, cultural, religious, ideological, political and 


\section{Gamze AKSAN, “Globalization and Civil Society or 'Global Civil Society"”,}

Mavi Atlas, 7(2)/2019: 150-176

economic or gender-based difference in the social life that is necessary for the development of civil society and for democracy to exist and none of these should become a tool of social repression.

This is a sociological rule and at the same time diversification, interdependence and solidarity progress in the right proportion. This differentiation must also have the qualities of social organization that can organize itself because civil society means to have an organization that will produce policy in differentiated areas. The essence of democracy is also based on the social age at which legitimate social organizations can be found and competed in legitimate ways in some rights claims. At the same time, these organized structures allow the development of civil society and the creation of a democratic environment by fulfilling functions such as socialization, politicization, political conscious raising in the society, dissemination of political culture and control mechanism over the state. However, these organizational structures need to be based on the voluntary nature. This puts individual rationality at the center as another precondition that society must bear. Moreover, these social groups need autonomous structures so that they can make their own decisions without being directed by the state. Another feature of being a pressure group is that it has activities that can both legitimate and democratically prevent the individual from being crushed under these structures by suppressing the state and free market (Çaha 2003: 62-64). These preconditions, which the state and the society must bear, give a concrete framework about the probability that these two phenomena, which are connected to each other by pointing directly to democracy, can be realized at an ideal level. As mentioned earlier, the sociological process of the concept of civil society is directly linked to globalization. If we are dealing with increasing globalization of interconnectedness and interdependence, and therefore centralizing social interaction, it is of course possible that the historical background of this phenomenon can be traced back to old times. This process, which was started by a group called "adventurers" on the road to globalization, continued until the end of the day, with the effect of the underlying motivations and interaction each of the merchants, warriors and preachers watched. Differences in the globalization process from the earliest times to the present are the speed at which products and ideas are transmitted, the increased volume of consumers and products, and their diversity, resulting in increased visibility as a result. Chanda (2009: 267-69) draws attention to the 1960s, when Sputnik and Amnesty International were founded, by mentioning the significant technological developments at this point of the effects of placeful and process-accelerating in our perceptions. In 1957, with the first artificial suit being thrown, Sputnik travels around the world in 96 minutes and emits a 


\section{Gamze AKSAN, “Globalization and Civil Society or 'Global Civil Society"”,}

Mavi Atlas, 7(2)/2019: 150-176

radio signal that can be heard from anywhere in the world. Thus, global communication begins and the world shrinks surprisingly. Over the years, the Apollo 11 spacecraft has been able to view the world's extended views by all television viewers, and these images become iconic images of the home planet. A different development is also experienced in the field of civil society. The year that globalization entered the dictionary in 1961, the World Wildlife Fund, the first non-governmental organization in the postwar world to protect planet, is created. In the same year, Amnesty International, the world's first human rights organization, is formed. Later, this situation continues to increase: in the fields of environmentalism, women's rights and human rights, the number of civil organizations representing social problems with their commonalities in society and similar groups starts to be founded.

Undoubtedly, the process of institutionalizing the modern social form of life and, accordingly, of a series of modern aspects of the political tradition, is certainly not independent of some of the influences of globalization. In most of today's society, recognizing it beyond as a political system, that the meaning the democracy as social life style and moral order becomes widespread is a result of globalization and it is simplest expression of this subject. In fact, the classical theoretical approaches we have considered within the statist and socialist / individualistic political tradition today are not independent of a number of global influences, but rather are directly linked to these effects. Martin Luther King, who launched the civil rights movement in the 1960s, says "I have a dream today"1, in cities as heterogeneous as possible with migrations; has led to the movement of significant influences and consequences for many societies, opposing the ideological and limited nature of the present political discourse that can not respond to the rights claims of individuals with different lifestyles and cultural, ethnic or religious differences.

Along with the beginning of the civil rights movement, civil society has begun to come to the fore more in practice. The basic motivation of this move was precisely civil

\footnotetext{
${ }^{1}$ The expressions of King reflect this situation quite strikingly. The following are some examples of problems that may be related to the potential of political representation, such as equality, civil rights, recognition, chances of survival: "So I say to you, my friends, that even though we must face the difficulties of today and tomorrow, I still have a dream. It is a dream deeply rooted in the American dream that one day this nation will rise up and live out the true meaning of its creed - we hold these truths to be selfevident that all men are created equal.... I have a dream my four little children will one day live in a nation where they will not be judged by the color of their skin but by content of their character. I have a dream today!... I have a dream...that one day, right there in Alabama, little black boys and black girls will be able to join hands with little white boys and white girls as sisters and brothers. I have a dream today!" (As cited in Gerd Baumann, Multicultural Riddle, Rethinking National, Ethnic and Religious Identities, Routledge, NY, 1999).
} 


\section{Gamze AKSAN, “Globalization and Civil Society or 'Global Civil Society",}

Mavi Atlas, 7(2)/2019: 150-176

rights, that is, equal rights based on equal and individual citizenship. According to Baumann (1999: 2), the American-centered tendency to turn from individual rights to collective rights movement was initially shaped from equal citizenship demands to ethnic rights and then to religious rights claims.

Societies that exist today need more of a democratic consciousness under the influence of globalization and a democratic consciousness settled at the moral level. Today, the mission of solving the problem of coexistence of differences has been put into modern democracy and democratic institutions. However, the relationship of globalization with democracy points to a different problem area that also concerns the field of civil society. With the globalization, the classical liberal democratic governments, which are the management style of the modern nation states, are not functioning in certain fields, and some problems are on the way as they can not adapt to the nature and speed of the changing structure and relations in the course of the process. As it has been practiced so far, democratic politics has assumed a self-governing national community, a sovereign nation. But the influence of globalization narrows the sovereignty of the nation (Giddens 2003: 78). The development of communication technologies and the intensified flow of international capital has deeply affected the understanding of space and space and the international political environment determined by modernity. While the nation-state perspective as a state-centered institution, nationalism as an ideology, and national identity as an individual overlap, a distinctly monist understanding of diversity and pluralism is seen as the focus of opposition that does not affect the structure of the system of differences. But the question that arises with the process is clear: how will the restrictive borders and free competition overlap? In particular, the neo-liberal movement that developed in the 1980s led to globalization and led to state policies that reduced or completely abolished state intervention in this axis of individualism and market empowerment. But before that, this process of integrating with the civilian movements that have increased in the $60 \mathrm{~s}$, and thus with the new social and political movements, which was mentioned before, has brought the issue of how to create politics for looser organizations and problems, to strengthen the horizontal relationship network and to withdraw the state (Kahraman et al. 1999: 15). Efforts were made to establish autonomous, self-organizing grounds outside the state in order to oppose the military dictatorship and the army in Latin America and Eastern Europe in the seventies and eighties. In addition, civil society has also gained a global reach as communications networks and travel possibilities developed, connecting as many different civil society groups as possible in different parts of the world. In the process up to the 90 's, these civil 


\section{Gamze AKSAN, "Globalization and Civil Society or 'Global Civil Society", Mavi Atlas, 7(2)/2019: 150-176}

groups, in response to a number of international organizations, created global spaces at the same time; Activists who came together to discuss issues such as human rights, landmines, climate change, dams, etc. in these places, strived for international agreements. This made the nineties meaningful for the emergence of transnational networks (Kaldor 2007: 153-55). The greatest contribution of the procession is to discuss, question and revise the classical approaches to democracy, the existing perception of democracy that has expanded, and the transnational inclusiveness of democracy that has increased.

All these developments bring a transition from the world of nation states to the global world, from the industrial society to the information society, from the modernist approach to the postmodernist approach to science, morality and aesthetic debates (Tekeli 1999). When we evaluate this process of transformation in terms of civi society, we see the questioning of the particularist and essentialist characteristics of modernization and the increased acceptance of postmodern thought with its emphasis on pluralist and multicentered world, hence the discussion of present democratic attitudes within this context. While the discussion of classical liberal democracies in the face of inadequate developments and the debates about democratic conventions is about how democracy can be better operated -by including some of the newly-developed discussions such asinclude dialogic democracy, participatory democracy, negotiating democracy, cosmopolitan democracy, democratization of democracy (see at. Benhabib 1994; Kahraman et al. 1999; Giddens 2003; Habermas 1991; 1996, McGrew 2014)-, this reveals the basic qualities of civil society, which is expected to be present with the "new human" model, which is actually on the way. This human being is now a human of a globalized world who is aware of his capacity, questioned and develops himself beyond being a largely homogenized citizen of the nation state (Tekeli 1999: 8). A moral and cultural need arises in public spaces that do not want to be determined by the system anymore, that see themselves as active subjects with collective motivations, and in which there are individuals in the right claims, who do not desire despotism and speak in pluralism, so democracy has been tried to be redesigned to meet this need. The global nature of risks, threats, claims and violations has also shaped the nature of civil rights claims in the public sphere and civil society has embodied a new form with global characteristics, depending on the change in the social age it is in. Now let's take a closer look at the theoretical and practical implications of the concept of global civil society. 


\section{Gamze AKSAN, “Globalization and Civil Society or 'Global Civil Society",}

\section{4. "Global Civil Society"}

From the classical concept of civil society to today's approaches, there are important differences in the practical reflection of the basic features that constitute the theoretical framework of the concept. At this point, Kaldor (2014: 662-64; 2007: 153) suggests that, under the influence of specific historical conjuncture, deriving the concepts of contemporary civil society and global civil society from classical definitions can prevent us from seeing the new realities of the concept and suggest that we should be cautious. In fact, while the old definitions of nation-state centralization accepted the existence of the state as an important data, the contemporary concept can be defined as a shift away from geographically-oriented state-centered approaches, necessitating the restructuring of both the social relations (for example empowering of individual and emphasis on personal autonmy) as well as intensifying interconnection as on the basis of the earth, such as social consciousness. When we try to understand the process in this framework, the two main areas are directly linked to the emergence of the global civil society term: The spread of democratization demands and the intensifying global interconnection process. This process, which is visible with the eighties (Eastern Europe), which has become more intense during the nineties (the collapse of closed societies, the spread of neoliberal ideas, the dramatic improvements in communication technologies), together with the expanding power of multinational corporations, has shaped international governmental organizations and transnational social movements. Thus, the increasing importance of globalization and international decision-making, as well as the state's limited ability to respond to democratic demands, is limiting the global community, and the opening of new possibilities for strengthening independent groups of citizens and independent political groups in authoritarian and closed societies is crucial in the sense of the historical and social position of global civil society.

On the other hand, it is also clear that global civil society needs the State for specific affairs. Global civil society actors need legal means to realize and systematize their own demands. Although international organizations criticize the state in practice, they need the state with the expectation of establishing legal and political frameworks that facilitate, for example, the establishment of the rule of law for the protection of human rights, the environment or civil and political rights (Chandhoke 2002: 51). If a global civilization process is possible, it is not right to base it on "the establishment of a world state." According to Kaldor (2014: 663-64), this will mean a concentration of power that can not be imagined, which will also affect the civil society sphere. Instead, the supremacy of international law, guaranteed by linked institutions, including citizens' 


\section{Gamze AKSAN, “Globalization and Civil Society or 'Global Civil Society"”,}

Mavi Atlas, 7(2)/2019: 150-176

networks, not only governments, but also inspectors, debates, and public opinion, should become widespread. In this sense, what we will define as global civil society should be the interactions of these groups, nets and movements that create a bridge between individuals and international institutions that provide voice to individuals in the global arena. On the other hand, Kenae (2003: 8) expresses the ideal meaning of global civil society in the world we live in:

a dynamic on-governmental system of interconnected socio-economic institutions that straddle the whole earth, and that have complex effects that are felt in its four corners. Global civil society is neither a static object nor a fait accompli. It is an unfinished project that consists of sometimes thick, sometime sthinly stretched networks, pyramids and hub-and-spoke clusters of socio economic institutions and actors who organise themselves across borders, with the deliberate aim of drawing the world together in new ways. These nongovernmental tend to pluralise power and to problematize violence; consequently, their peaceful or 'civil' effects are felt everywhere, here and there, far and wide, to and from local areas, through wider regions, to the planetary level itself.

This definition emphasizes five attributes of global civil society that are firmly connected: non-governmental, a society of mutually connected social processes, civilityoriented (non-violence), plural (which also has a strong potential to reduce conflict), and is global. In addition, Keane defends the notion that "civil society does not exist if there is no market", unlike the views that judge civil society from the market or the nation state literally. According to this view, markets and civil society areas are buried in each other, and civil society can not survive without market, money and money economy. In this connection, employees on the market benefit from the socialization rules of civil society such as "regularity, trust, honesty, credibility, non-violence and group obligation". On the other hand, markets are the preconditions that have been intertwined in functional terms as structural empirical features of social relations existing in global civil society. Capitalist market forces can not exist without other civil society institutions covering social norms such as parents, charities, community associations, friendship, trust, cooperation (Ritzer 2010: 133). In fact, this situation also reveals the history of the concept of global civil society. If we assume that the field of civil society is an area with all the dynamics of publicity between the state and society, it is obvious that in today's capitalist societies, as in other fields, this domain is also determined by capitalist market relations. Moreover, the activities of multinational corporations and organizations that emerged in the direction of capitalism also cause known opportunities and risks or threats on all sides of the world, while civil society elements also exist in supportive or opposed 


\section{Gamze AKSAN, “Globalization and Civil Society or 'Global Civil Society",}

Mavi Atlas, 7(2)/2019: 150-176

actions by developing a common language in this context. The most beautiful example of this is the environmental movements resulting from the global warming, factory wastes and wastewater problems with the rexlex of "protecting of the world". Today, many different individuals from different societies against, for example, the nuclear power plant to be established by a global company anywhere in the world can influence the decisions of governments and multinational corporations with their activities under some global non-governmental organizations.

Jeffrey Alexander (2006: 523) provides an insight into the influence of the media in the formation of the process, and let us to see the different aspects that motivate the formation of global civil society. The global civilian space we can think of as young and immature does not yet make possible the existence of a fully functioning democracy that allows the creation of a public opinion that can create civilian power to regulate the state with the independence of institutions such as judiciary, election or political competition. But this fully immature civilian space has access to the institutions of a more communicative form. Despite the different economic levels, languages and forms of organization, national news usually builds such "over-national" events that bring about a high degree of intertextuality by producing common perceptions and interpretations that are global in nature. These 'factual' understandings are sustained by the intense circulation around the globe of 'fictional' mass media, which are far from being merely entertaining in their cultural effects. These fictional media are movies, television dramas, novels, music, and the international brands whose consumption is creating a more common material culture worldwide. Thus, the institutional and symbolic construction of the global public is emerging on the world scene, producing a supra-national perception. This exciting and dynamic global consciousness represents the global face of civil society by creating different forms of governance through international institutions and nongovernmental organizations.

Although the approaches to global civil society are diversified, it is stated that they do not offer a specific theoretical framework and they are placed in a haphazard manner without being firmly grounded (see at. Waterman 1996; Taylor 2002; Amoore and Langley 2004). Indeed, the transformation of the concept in the historical process and the parameters that determine it, as well as the reasons for the emergence of global civil society, reveal many facts about reality. But it is also known that many of today's approaches have been vague in certain aspects, since the postmodern structure of thought has been avoided by the increasing influence of the structure of thought, as in modern times, in the sharp, central and overarching theoretical approach. In addition, the 


\section{Gamze AKSAN, “Globalization and Civil Society or 'Global Civil Society"”,}

Mavi Atlas, 7(2)/2019: 150-176

intertwined structure of highly complex social phenomena that constitute the social reality with the same periodical character makes it difficult to constitute a definite definition in this area. Therefore, the theoretical approaches to the concept of global civil society seem to be based on a number of dynamics of the historical process, with very clear boundaries. The works of Mary Kaldor, one of the first names in the literature on global civil society, reflects important data, including descriptions of helping to clarify the concept. For example, Kaldor (2003: 7-10), who explains the answer to the question of what global civil society implies in the "global" context through five basic versions, presently provides an analytical framework for global civil society debate. While the first two of the five basic versions mentioned include the old primitive contexts of the concept in the historical process, the rest of the approaches point to the fact that today's conditions revealed from the echoes of the reality. But the first two levels are not independent of the conditions of globalization. According to this view, the first version of the term "societas civilis" is the domain of civilization in which the political society under the rule of law is openly or implicitly dominated by a peaceful order based on the interests of the individual. This version, which has similar content to Kant's universal civil society, defines a field based on a cosmopolitan legal supremacy guaranteed by international agreements and institutions. The second version is bourgeois society as the area in which ethical life is represented between Hegel and Marx's ideas, including the views of Ferguson and Smith. As a phenomenon that has emerged in the history of capitalist relations as we have already mentioned, the market refers to a civil society area consisting of social classes, civil law and social assistance institutions. The activist version reflects the democracy's radicalization, participation and autonomy, as it historically tells us the closest European, sometimes utopian, or Post Marxist version, the European-centered opposition in the '70s and' 80s. Aforementioned period is an important period in which global institutions such as Amnesty International emerged, and the practical aspects of global civil society, where protests in cities like Seattle, Prague and Genoa, are made visible. The conditions that coincided with the developments in 1989 represent the neo-liberal version. It expresses a period where market-oriented policies are dominant and çivil society represents an organizational life. It is a period in which voluntary units that are not aimed at profit are not only restricted to the state but also increase their sustainable functions in the public interest. Finally, the postmodern version separates the universality of the activist and neoliberal versions and requires tolerance as a universal rule. In this version, cosmopolitanism, as shared by activists, is more meaningful as civil society preoccupies multiple identities as well as national and religious identities. 


\section{Gamze AKSAN, “Globalization and Civil Society or 'Global Civil Society"”,}

Mavi Atlas, 7(2)/2019: 150-176

The history of the global forms of non-governmental organizations, the institutional elements of civil society, is not too old. It is stated that these institutions dating back to the 19th century first started with anti-slavery movements (British and Foreign Anti-Slavery Society) in 1839. While the number of registered organizations in the last quarter of the 1800s was 32, in 1914 this number increased to 1083. After the Second World War, the numbers increased rapidly. However, the actual concentration occurred after the 1990s. Civil society relations have started to become much more visible in the 1990s, especially after the global movement has been established since then, almost a quarter of the international non-governmental organizations that exist in the World (Anheier et al. 2001:4). This data reminds us of the impact of the shift to information society and the increase of communication technologies in motivating civic organizations. Since the 1990s, a variety of movements and organizations representing the vital unions of global civil society have come together. Some of these organizations include transnational activists involved in activities that address issues such as global warming, AIDS, landmines. With the alternative globalization movement, especially antiwar movements revived after the invasion of Iraq have an important place in this field. Organizations that are mainly engaged in areas such as the environment, human rights and economic development are becoming increasingly important in this field. The most notable ones are CARE, WWF, Greenpeace, Amnesty International, World Friends Organization, Doctors Without Borders (MSF) and Oxfam. In particular, the groups representing the poor in economically underdeveloped countries and their efforts to improve the position of the poor in the global economy represent perhaps the most important status in terms of civil society. In this framework, global civil society has become increasingly similar to social customs, and has become a form in which common claims on the basis of humanity are reflected, while at the same time it has become a form of oppression by reaching a strong level. For example, the sighting of World Bank funding strategies and the formal representation of the World Economic Forum in Davos, Switzerland, are significant achievements of global civil society elements. At the same time, some intergovernmental organizations, such as UNESCO, the United Nations, have been able to cooperate with international non-governmental organizations to gain financial support or to be quickly supported by their activities (Ritzer 2010: 163-164). Ritzer (2010: 166) points out that this can lead to negative consequences such as the loss of the flexibility of global civil society elements, the loss of identity and autonomy. Therefore, states' attitudes are still crucial for civilian organizations to be "civilians" even 


\section{Gamze AKSAN, “Globalization and Civil Society or 'Global Civil Society"”,}

Mavi Atlas, 7(2)/2019: 150-176

though they have overtaken their democratic attitudes in the process of global civilian consciousness and revised their deficient areas.

\section{Conclusion}

Civil society has gained a central position in the discussions of more ethical pluralism of differences in heterogeneous public spaces, now under the influence of globalization, while it is a key concept showing the boundaries and relation of the state and the society, which became evident in the debate about democracy and liberalism first with the state context. The concept, along with the historical and social reality it represents, has an area of analytic debate, both at the level of social institutions and in the process of individual interaction, that determines the main character of ideas that concern a range of boundaries and areas of responsibility. The changing social tendencies along with the globalization process and the conclusion of this situation at the same time with some social events have influenced the formation of a global civilian initiative field by clarifying the processes and objections of the modernist criticism of the monarchist structure. While civil society is important in this context in many aspects of political science and sociology, the characteristics of organized organizations that can bring the differences together and turn them into potential benefits are gaining importance in the context of social networks and social capital debates. In the process, an important area of debate about civil society is also the relationship of this concept to the state and the market. The radical ideas developed in this framework bring about the problem of distancing the concept from reality. Indeed, global civil society can lead to a totally independent view of the market and the money economy by making some differences, which, as seen in some pioneering perspectives, may remain the only utopian ideal, without being placed in a historical context. But seeing global civil society as being completely dependent on market conditions can also negatively affect the view of this phenomenon in terms of its internal morality and its autonomous structure that produces value codes. It can be demoralizing by losing the idealist side if the individual reduces the active aspects that excite and dynamite them to a simple dependency relation. Therefore, making ideal interpretations without distancing the concept from reality and its possibilities in this matter will give more realistic results. As a result, when considering the relationship between globalization and civil society as evaluating existing data, the relationship with the state, democratic debates and social movements and institutional organizations become visible. While increasing demands for democracy and the attitude of states in this area are the main determinant of the civilian field, it is necessary to develop common understanding and reactions against the situations that take place on the 


\section{Gamze AKSAN, “Globalization and Civil Society or 'Global Civil Society"”,}

Mavi Atlas, 7(2)/2019: 150-176

world through the influence of the concentration in the communication networks reinforced through some virtual environments through the communication technologies. When the political history of the world is assessed, it seems undoubtedly promising in the name of humanity. However, war risks or security threats can directly affect democratic environments, and states can intervene in the civilian space for some reason, limiting democratic rights. For example, the debate over global citizenship and removing the borders (popularized by US President Obama's voice in 2013) was on the agenda several years ago, the problem of the refugees that broke out in the war in Syria today, and a series of social problems stemming from it, and also the terrorist movements in the global dimension have been leading many states to take territorial nation-based security measures. For this reason, the rights of victims of people with religious and ethnic differences in different societies are coming back to the present day. This rapid transformation of the borders of reality to complex processes, although causing a pessimistic picture in the context of civil rights, allows people with completely different lifestyles to go beyond the limits of their ability and encourage them to develop initiatives on the main issues of humanity. Therefore, the phrase "global civil society" is very functional in order to achieve awareness in the society at macro, meso and micro levels and reach a more ideal civilian and public sphere in the name of future human rights, differences and boundaries of coexistence.

\section{References}

AKAL, Cemal B. (1991). Sivil Toplumun Tanrısı, İstanbul: Afa Yayıncılık.

AKTAY, Yasin (2015). Postmodern Kavşakta Din ve Sivil Toplum, İstanbul: Tezkire Yayıncilik.

ALEXANDER, Jeffrey (2006). "Global CivilSociety”, Theory, Culture \& Society, SAGE, 23 (2-3): 521-524.

AMOORE, L. \& Langley, P. (2004), "Ambiguities of Global Civil Society", Review of International Studies, 30: 89-110.

ANHEIER, H., Glasius, M.Kaldor, M. (2001), "Introduction Global Civil Society", Global Civil Society, eds. H. Anheier, M. Glasiusand and M. Kaldor, pp. 3-22, Oxford: Oxford Universty Press,.

ASLAN, Seyfettin (2010). "Civil Society: Conceptual Alteration and Transformation, Electronic Journal of SocialSciences, 9(33): 188-212. 


\section{Gamze AKSAN, “Globalization and Civil Society or 'Global Civil Society",}

BAUMANN, Gerd(1999). Multicultural Riddle, Rethinking National, Ethnic and Religious Identities, NY: Routledge.

BENHABIB, Seyla (1994). Deliberative Rationality and Models of Democratic Legitimacy, Constellations, 1(1): 26-50.

BERLIN, Isalah (1969). "Two Concepts of Liberty", in "Four Essays on Liberty" pp. 118-134, Oxford: Oxford University Press.

BOLAY, S. Hayri (1997). "Sivil Toplum ve Manası", Yeni Türkiye Sivil Toplum Özel Sayısl, 18: 7-9.

CARNOY, Martin (2001). “Gramsci ve Devlet”, Praksis (3) 2001: 252-278.

CAROTHERS, Thomas (2000). “Civil Society”, Foreign Policy, 117 (Winter): 18-29.

CHANDA, Nayan (2009). Küreselleşmenin Sıra Dışı Öyküsü: Tacirler, Vaizler Maceraperestler ve Savaşçılar Globalizmi Nasıl Şekillendirdiler, Ankara: ODTÜ Yayıncilik.

CHANDHOKE, N. (2002). "The Limits of Global Civil Society", Global Civil Society, Eds. M. Glasius, H. Anheier, \& M. Kaldor, pp. 35-53, NY: Oxford University Press.

CHUI, W. H. \& LEUNG, E. W. Y. (2014). "Youth in a Global World: Attitudes Towards Globalization and Global Citizenship Among University Students in Hong Kong”. Asia Pacific Journal of Education 34(1): 107-124.

COX, Robert W. (1999). "Civil Society at theTurn of the Millenium: Prospects for an Alternative World Order”, Review of International Studies, 25: 3-28.

ÇAHA, Ömer (2003). Aşkın Devletten Sivil Topluma, İstanbul: Gendaş Kültür Yayınları.

WOOD, Ellen M. (1990). "The Uses and Abuses of 'Civil Society"”, The Socialist Register, 26: 60-84.

HEGEL, G. W. F. (2010). Elements of the Philosophy of Rights, ed. Allen W. Wood, Cambridge: Cambridge University Press.

GIDDENS, Anthony (2003). Runaway World: How Globalisation is Reshapingour Lives, NY: Routledge. 


\section{Gamze AKSAN, “Globalization and Civil Society or 'Global Civil Society"”,}

GIDDENS, Anthony (2016). Sosyoloji, 7. Edisyon, İstanbul: Kırmızı Yayınları.

HABERMAS, Jurgen (1991). The Structural Transformation of the Public Sphere, Translated By: Thomas Burger, Cambridge: Massachusetts MIT Press.

HABERMAS, Jurgen (1996). "Three Normative Models on Democracy", Democracy and Difference Contesting the Boundaries of the Political, ed. Seyla Benhabib, pp. 21-31, New Jersey: Princeton University Press.

HAYEK, F. A. (1999). Kölelik Yolu, çev. Turhan Feyzioğlu, Ankara: Liberte.

HAYEK, F.A. (1995). Kanun, Yasama ve Özgürlük: Sosyal Adalet Serabı, çev. Mustafa Erdoğan, Ankara: Türkiye İş Bankası Yayınları.

HOBBES, Thomas (1977), Leviathan; or the Matter, Forme, and Power of a Common-.Wealth, Ecclesiasticall and Civil, 13th. Printing, New York: Collier Books (Macmillan Publishing Co.,Ine.).

KAHRAMAN, H.B, Keyman, F., \&Sarıbay A.Y. (1999). Katılımcı Demokrasi, Kamusal Alan ve Yerel Yönetim, İstanbul: Dünya Yerel Yönetim, Demokrasi Akademisi Yayını (WALD).

KALDOR, M. (2003). Global Civil Society: An Answer to War, Polity Press: Cambridge.

KALDOR, Mary (2007). "Civil Society”, Encyclopedia of Globalization, Ed. Jan Aart Scholte, Roland Robertson, NY: MTM Publishing.

KALDOR, Mary (2014). “Küresel Sivil Toplum”, Küresel Dönüşümler: Büyük Küreselleşme Tartışması, 2. Baskı, ed. David Held \& Anthony McGrew, Çev. M. Celil Çelebi, pp. 662-667, Ankara: Phoenix Yayınları.

KEANE, John (1988). Democracy and Civil Society: On the Predicaments of European Socialism, the Prospects for Democracy, and the Problem of Controlling Social and Political Power, NY: Verso Books.

LOCKE, John (1823). Two Treatises of Government, From The Works of John Locke, A New Edition, (Corrected in Ten Volumes), Vol. V, Dublin: McMaster University Archive.

MALESEVIC, Sinista\& MALESEVIC, Vesna (2009). "Civil Society Theory: Gellner", International Encyclopaedia of Civil Society, eds. H.K. Anheierand S. Toepler, NY: Springer. 


\section{Gamze AKSAN, “Globalization and Civil Society or 'Global Civil Society"”, Mavi Atlas, 7(2)/2019: 150-176}

McGREW, Anthony (2014). "Ulus-Ötesi Demokrasi Modelleri”, Küresel Dönüşümler: Büyük Küreselleşme Tartışması, 2. Baskı, eds. David Held, AnthonyMcGrew, Çev. Ezgi Sarıtaş, ss. 591-609, Ankara: Phoenix Yayınları.

O’BYRNE, D. J. \& HENSBY, A. (2011). Theorizing Global Studies. New York: Palgrave Macmillan.

POLLOCK, Frederick (1904). "Locke's Theory of the State" Proceedings of the British Academy, 2: 237-49.

RAWLS, John (2003), A Theoryof Justice, 8th. Printing, USA: Harward University Press.

RITZER, George (2010). Globalization: A basic Text, UK: Wiley-Blackwell Publishing.

ROWLEY Charles K. (1997). "On the Nature of Civil Society”, The Independent Review, II(3): 401-420, Winter.

SELIGMAN, Adam B. (2002). "Civil Society as a Idea and Ideal", Alternative Conceptions of Civil Society, Eds. Simone Chambers and Will Kymlicka, pp. 13-34, USA: Pinceton University Press.

TAYLOR, Rupert (2002). "Interpreting Global Civil Society", Voluntas: International Journal of Voluntary and Nonprofit Organizations, 13( 4) : 339-347.

TEKELI, İlhan (1999). "Önsöz”, Katılımcı Demokrasi, Kamusal Alan ve Yerel Yönetim, eds. H.B Kahraman, F. Keyman ve A.Y. Sarıbay, İstanbul: Dünya Yerel Yönetim, Demokrasi Akademisi Yayını (WALD).

VINOD, M.J. \& DESHPANDE, M. (2013). Contemporary Political Theory, Delhi: PHI Learning Private Limited.

WATERMAN, P. (1996). "Beyond Globalismand and Developmentalism: Other Voices in World Politics", Dev. Change 27(1):165-180.

YILMAZ, Aytekin (1997). "Sivil Toplum, Demokrasi ve Türkiye”, Yeni Türkiye Sivil Toplum Özel Sayıs1, Sayı 18: 86-98. 